\title{
PRZEGLĄD PIŚMIENNICTWA WŁOSKIEGO W ZAKRESIE REGULACJI PRAWNYCH DOTYCZĄCYCH GOSPODAROWANIA ODPADAMI
}

\section{REVIEW OF THE LITERATURE ON THE ITALIAN REGULATIONS ON WASTE MANAGEMENT}

\section{STRESZCZENIE W JĘZYKU POLSKIM}

W opracowaniu zasygnalizowano ostatnie zmiany w prawodawstwie włoskim, które mają służyć udoskonaleniu istniejących już przepisów w zakresie gospodarowania odpadami, a także wskazano najważniejsze i najbardziej aktualne publikacje $\mathrm{w}$ ramach tej problematyki. Włochy od dłuższego czasu walczą z problemem niewydolnego systemu funkcjonowania gospodarki odpadami, w związku z tym - w ostat-

* Doktor nauk prawnych; adiunkt w Katedrze Prawa Cywilnego Europejskiej Wyższej Szkoły Prawa i Administracji, Kancelaria Radców Prawnych s. c. dr K. Szuma, H. Zambrowicz-Rybarczyk w Poznaniu. 
nich latach, a zwłaszcza w ostatnich miesiącach - próbuje się przeorganizować system zarządzania i gospodarowania odpadami poprzez wprowadzanie zmian przepisów prowadzących do ich udoskonalenia oraz tworzenie nowych instytucji. W roku 2009 powstał tzw. SISTRI. System ten upraszcza procedury oraz wykonywanie obowiązków w zakresie gospodarowania odpadami poprzez redukcję kosztów ponoszonych przez przedsiębiorstwa gospodarujące odpadami. W jego ramach przewidziano unowocześnienie, uelastycznienie, a zwłaszcza uczynienie bardziej przejrzystym całego procesu gospodarowania odpadami. System ma też na celu zmniejszenie ryzyka działań niezgodnych z prawem. Publikacja zawiera przegląd piśmiennictwa włoskiego w zakresie gospodarki odpadami, wskazuje opracowania, które szerzej wyjaśniają proces ostatnich zmian.

Słowa kluczowe w języku polskim

Odpady, gospodarowanie odpadami, SISTRI.

\section{STRESZCZENIE W JĘZYKU ANGIELSKIM}

In the article there are mentioned the recent changes in the Italian legislation, the aim of which is to improve the binding provisions on the waste disposal. The article is focused on the most important and most up-to-date publications within the issue. Italians have been trying to solve the problem of inefficient system of waste disposal for some time. Therefore, in recent years and particularly in the last months there has been an attempt to reorganize the system of management of waste disposal by introducing some amendments in regulations and updating the binding regulations and creating new institutions. In 2009 the so called SISTRI system was introduced and it has simplified the procedures and the execution of obligations with respect to the waste disposal by the reduction of costs incurred by enterprises managing waste disposal. In the framework of this system there has been foreseen the modernization of the system and getting the whole system of waste disposal more flexible and transparent. The purpose of the system is to reduce the risk of activities violating the law. The publication includes the review of the Italian literature in respect of the waste disposal and indicates a few Italian publications which explain the process of the last 1/2011 changes in more detail. 


\section{Słowa kluczowe w języku angielskim}

Waste, waste management, SISTRI.

Poprawa jakości legislacji wspólnotowej jest ważnym elementem mieszczącym się $\mathrm{w}$ katalogu zadań realizowanych ramach strategii lizbońskiej ${ }^{1}$. Inicjatywa poprawy jakości przepisów unijnych dotyczy również prawnych systemów poszczególnych państw członkowskich. Zakres poprawy jakości legislacji można odnieść do wielu płaszczyzn, w tym również do przepisów dotyczących ochrony środowiska.

Ochrona środowiska jest taką dziedziną, w której od pewnego czasu nie zmieniają się priorytety. Przedmiot regulacji unijnych staje się coraz szerszy i bardziej szczegółowy, jednak ciągle towarzyszą mu założenia zmierzające do poprawy jakości środowiska.

Przedmiotem tego opracowania będzie przedstawienie ostatnich zmian w prawodawstwie włoskim, które to zmiany mają służyć udoskonaleniu istniejących już przepisów w zakresie gospodarowania odpadami, a także zasygnalizowanie najważniejszych i najbardziej aktualnych publikacji w ramach tej problematyki.

Włochy od dłuższego czasu walczą z problemem złego systemu funkcjonowania gospodarki odpadami, w związku z tym, w ostatnich latach, a szczególności w ostatnich miesiącach próbuje się przeorganizować system zarządzania i gospodarowania odpadami w postaci wprowadzanych zmian przepisów prowadzących do ich udoskonalenia oraz tworzenia nowych instytucji.

W pierwszej kolejności należy zwrócić uwagę na fakt powstania w roku 2009 tzw. SISTRI ${ }^{2}$. System ten powstał z inicjatywy Ministerstwa Środowiska i Ochrony Terytorium oraz Akwenów Morskich $^{3} \mathrm{w}$ ramach szerszego Planu Innowacji i Modernizacji

1 Zob. Komunikat Komisji dla Rady i Parlamentu Europejskiego, Better Regulation for Growth and Jobs In the European Union, COM(2005) $97 \mathrm{z}$ dnia 16 marca 2005 r., s. 2.

2 Sistema di controllo della tracciabilità dei rifiuti - system kontroli obrotu odpadami.

3 Ministero dell'Ambiente e della Tutela del Territorio e del Mare. 
Administracji Publicznej. System ten utworzono w celu pełnej informatyzacji obrotu odpadów problematycznych na poziomie krajowym oraz rejestracji obrotu odpadów komunalnych w Regionie Kampania ${ }^{4}$. Oprócz tego system upraszcza procedury oraz wykonywanie obowiązków w zakresie gospodarowania odpadami poprzez redukcję kosztów ponoszonych przez przedsiębiorstwa gospodarujące odpadami. Unowocześnia, uelastycznia, sprawia, że jest bardziej przejrzystym proces gospodarowania odpadami, zmniejsza ryzyko działań niezgodnych z prawem ${ }^{5}$. Zarządzanie procesem kontrolnym w SISTRI zostało powierzone Dowództwu Karabinierów Środowiska ${ }^{6}$. SISTRI jest powiązane organizacyjnie $\mathrm{z}$ wieloma instytucjami włoskimi, których nadrzędnym celem jest dbałość o zachowanie i poprawę stanu środowiska7. SISTRI daje możliwość pełnej i nieprzerwanej kontroli elektronicznej nad flotą wwożącą i wywożącą odpady na wysypiska. Taka organizacja daje kontrolę nad przemieszczaniem odpadów. Oprócz systemu informatycznego w praktyce istnieją trzy dokumenty w wersji papierowej mające znaczenie w obrocie odpadami. Pierwszy dokument stanowi tzw. formularz identyfikacji odpadów, drugi - rejestr

4 Zob. P. Kowalczuk, Mieszkańcy Neapolu protestują, góry śmieci rosnq, „Rzeczpospolita” z dnia 7 stycznia 2008 r.: „Kryzys z wywozem śmieci trwa w Kampanii od 15 lat. Ten południowy region stał się śmietnikiem uprzemysłowionej północy Włoch. Złotym interesem, jakim jest wywóz i utylizacja śmieci, szczególnie toksycznych, zajęła się kamorra. Oferowała swoje usługi fabrykom za połowę ceny rynkowej. Część toksycznych odpadów nie trafiała jednak do spalarni, do dziś są zakopywane gdzie popadnie na terenach należących do mafii. Śmieci importowane nielegalnie z północy oraz z zagranicy przepełniły wysypiska i zwykłych odpadów z Kampanii nie ma gdzie wywozić. Kamorra blokuje budowę wielkich spalarni, bo zrujnowałoby to jej „ekologiczny” interes. Permanentny kryzys jest mafii na rękę. To właśnie do niej trafiła większość z 14 mld euro, jakie rząd wydał, by rozwiązać problem. Skorumpowane bądź zastraszone władze nie reagują. Paradoksem jest to, że w tej chwili śmieci z Kampanii wywożone są do spalarni odpadów w Niemczech za horrendalną cenę 200 euro za tonę. Niemcy zarabiają zaś podwójnie, bo przy okazji produkują i sprzedają energię elektryczną. A Włosi sprowadzają prąd z zagranicy".

5 www.sistri.it

6 Comando Carabinieri per la Tutela dell'Ambiente.

7 Np. ISPRA - Istituto Superiore per la Protezione e la Ricerca Ambientale, albo Nazionale dei Gestori Ambientali, Ministero dell'Ambiente e della Tutela del Territorio e del Mare, czy Guardia Costiera e delle Imprese Ferroviarie. 
przyjęcia i przekazania odpadów oraz trzeci- tzw. MUD ${ }^{8}$, pozwalający na identyfikację wytwórcy odpadów, podmiotu dokonującego odzysk, transportującego odpady oraz ewentualnego sprzedawcy odpadów dla podmiotu zajmującego się ich utylizacją.

Poszczególne Regiony zobowiązane są usprawnić i uprościć procedury prawne z zakresie całego procesu gospodarowania odpadami. Cała ta procedura ma doprowadzić do unowocześnienia, usprawnienia i przyspieszenia gospodarowania odpadami. Nadrzędnym celem jest jednak doprowadzenie do gospodarowania odpadami zgodnie z prawem? ${ }^{9}$.

Przegląd piśmiennictwa włoskiego w związku ze znaczącymi zmianami w zakresie gospodarki odpadami pozwala na wyliczenie kilku publikacji, które szerzej wyjaśniają proces zmian.

Po pierwsze, na uwagę zasługuje przewodnik po ostatnich zmianach autorstwa M. Rizzuto, C. Sanna, Guida all'applicazione del SISTRI. Adempimenti, procedure e sanzioni, wyd. EPC Libri, Roma 2010. Autorzy wskazują krok po kroku proces wprowadzenia w życie założeń nowego systemu gospodarowania odpadami. Przedstawiają również problemy, z którymi spotykają się uczestnicy tego systemu. Publikacja ma na celu przede wszystkim udzielenie odpowiedzi na najczęściej pojawiające się pytania dotyczące stosowania w praktyce nowych procedur. Autorzy rozwiązują wątpliwości i starają się ułatwić odnalezienie się w tym systemie przedsiębiorcom gospodarującym odpadami. Ułatwieniem w zrozumieniu poszczególnych procedur jest gra-

8 Modello Unico di Dichiarazione ambientale.

9 Podstawowymi aktami normatywnym wprowadzającymi nowy system gospodarowania odpadami są: Decreto ministeriale z dnia 17 grudnia 2009 r. nt. Istituzione del sistema di controllo della tracciabilita' dei rifiuti, ai sensi dell'art. 189 del decreto legislativo n. 152 del 2006 e dell'art. 14-bis del decreto-legge $n$. 78 del 2009, G.U. z dnia 13 stycznia 2010 r. n. 9; Decreto Ministriale z dnia 22 grudnia 2010 r. nt. Modifiche ed integrazioni al decreto 17 dicembre 2009, recante l'istituzione del sistema di controllo della tracciabilità dei rifiuti, G.U. z dnia 28 grudnia 2010 r. n. 30; Decreto Ministeriale z dnia 9 lipca 2010 r. nt. Modifiche ed integrazioni al decreto 17 dicembre 2009, recante l'istituzione del sistema di controllo della tracciabilita' dei rifiuti, ai sensi dell'articolo 189 del decreto legislativo n. 152 del 2006 e dell'articolo 14-bis del decreto-legge $n .78$ del 2009, convertito, con modificazioni, dalla legge n. 102 del 2009, G.U. z dnia 13 lipca 2010 r. n. 161. 
ficzne przedstawienie wielu zagadnień. Z opracowania wynika, że gospodarowanie odpadami powinno opierać się na następującej hierarchii postępowania z odpadami, stanowiącej kolejność priorytetów w przepisach prawa i w polityce: zapobieganie, przygotowywanie do ponownego użycia, recykling, inne metody odzysku, np. odzysk energii, oraz unieszkodliwianie. Dodatkowo publikacja zawiera tekst ustawy z dnia 17 grudnia 2010 r. wprowadzającej nowy system kontroli gospodarowania odpadami oraz jej schemat graficzny.

Kolejną publikacją o charakterze praktycznym jest książka autorstwa P. Cinquina, Rifiuti. Manuale tecnico-normativo, wyd. Sistemi Editoriali, Pozzuoli 2010. Autorka nawiązuje do dyrektywy $2008 / 98 / \mathrm{WE}^{10}$. Wskazuje się tu na problemy w procedurze wdrożenia postanowień tej dyrektywy do systemu prawa włoskiego. Publikacja ma charakter analizy autorskiej przepisów wspomnianej dyrektywy z elementami technicznymi, tj. zawiera w kilku miejscach schematy graficzne mające pomóc zrozumieć czytelnikowi niektóre instytucje. Autorka wskazuje, że we Włoszech szczególną uwagę należy zwrócić na wzmocnienie działań w zakresie ponownego wykorzystania odpadów i zapobiegania ich powstawaniu, recyklingu oraz innych form odzysku. Podkreśla ona, że nie tylko Włochy, ale również pozostałe państwa członkowskie mogą podjąć środki prawodawcze lub inne niż prawodawcze w celu zapewnienia, aby każda osoba fizyczna lub prawna, która zawodowo opracowuje, wytwarza, przetwarza, obrabia, sprzedaje lub wwozi produkty, ponosiła rozszerzoną odpowiedzialność. Środki takie mogą obejmować przyjmowanie zwracanych produktów i odpadów pozostających po wykorzystaniu tych produktów, a także późniejsze gospodarowanie tymi odpadami i odpowiedzialność finansową za te działania. Odwołując się do postanowień dyrektywy 2008/98/WE autorka podkreśla, że Włochy mają szczególny problem w zakresie zastosowania odpowiednich środków zachęcających do takiego projektowania

10 Dyrektywa Parlamentu Europejskiego i Rady 2008/98/WE z dnia 19 listopada 2008 r. w sprawie odpadów oraz uchylająca niektóre dyrektywy, Dz. Urz. UE L 312 z 22.11.2008, s. 3-30. 
produktów, aby zmniejszyć ich oddziaływanie na środowisko, a także z wytwarzaniem odpadów podczas produkcji.

Innym godnym uwagi opracowaniem odwołującym się do trudnej sytuacji w gospodarce odpadami we Włoszech jest publikacja O. Busi, Quaderno di polizia ambientale: i rifiuti, wyd. Halley Editrice, Matelica 2010. Autor odwołuje się do zmieniających się przepisów ze szczególnym uwzględnieniem nowelizacji kodeksu środowiskowego ${ }^{11}$. Nadto wskazuje na koncepcję tzw. Policji środowiskowej ${ }^{12}$ opierającej się na założeniu, że skuteczne zwalczanie przestępczości i antyspołecznych zachowań wymaga bliskiej współpracy Policji z członkami społeczności lokalnej. Instytucja ta powinna mieć również przełożenie na sprawy środowiska, a w szczególności na gospodarowanie odpadami. Autor zwraca szczególną uwagę na fakt, że państwa członkowskie zobowiązane są podejmować środki niezbędne do zapewnienia, aby produkcję, zbieranie i przewóz odpadów niebezpiecznych oraz ich magazynowanie i przetwarzanie przeprowadzano w warunkach gwarantujących ochronę środowiska i zdrowia ludzkiego. Oprócz tego niezbędne jest podejmowanie w państwach członkowskich środków służących ustaleniu obiegu odpadów od momentu produkcji do miejsca przeznaczenia oraz kontroli odpadów niebezpiecznych.

Na uwagę zasługuje również Il nuovo codice dei rifiuti. Commentato con la giurisprudenza, red. L. Ramacci, wyd. La Tribuna, Piacenza 2011. Publikacja kierowana jest do prawników stosujących prawo o odpadach na co dzień. Oprócz najnowszych nowelizacji tekstów prawnych dotyczących nie tylko odpadów, ale również elementów środowiska ściśle z odpadami powiązanych $^{13}$, publikacja zawiera także komentarz przedstawicieli doktryny.

11 Decreto Legislativo z dnia 3 kwietnia 2006 r., n. 152 - Norme in materia ambientale, G.U. z dnia 14 kwietnia 2006 r. n. 88.

12 Ang. Community policing lub neighbourhood policing.

13 Publikacja zawiera treść Decreto Legislativo z dnia 10 grudnia 2010, n. 219 dotyczący wód, Decreto Legislativo z dnia 3 grudnia 2010, n. 205 dotyczący odpadów czy Decreto Ministeriale z dnia 17 grudnia 2009, n. 219 w sprawie systemu kontroli obrotu odpadami. 
Ponadto godną uwagi jest też publikacja autorstwa M. Rosalba, Compendio normativo per la gestione dei rifiuti e la bonifica dei siti inquinati - Commento organico della Parte IV, coordinata con la Parte I, del codice dellambiente Aggiornato al D.P.C.M. 27 aprile 2010. Modifiche al Modello unico di dichiarazione ambientale, wyd. Maggioli Editore, Santarcangelo di Romagna 2010. Opracowanie to zawiera omówienie wszystkich przepisów w zakresie gospodarki odpadami, począwszy od kodeksu środowiskowego, a skończywszy na regulacjach wydawanych przez Regiony. Autor odwołuje się także do uwarunkowań historycznych i nawiązuje do pierwszych regulacji włoskich w zakresie omawianej materii. Podkreśla rangę i analizuje normy prawa unijnego, przede wszystkim dyrektywy 2008/98/WE. Autor krytycznie ocenia włoski system przepisów regulujących sprawy gospodarowania odpadami. Opracowanie kierowane jest w szczególności do praktyków, organów administracji publicznej oraz wszystkich, którzy potrzebują publikacji integralnej, a zarazem w jasny sposób obrazującej system gospodarki odpadami we Włoszech.

\section{BIBLIOGRAFIA}

Busi O., Quaderno di polizia ambientale: i rifiuti, Matelica 2010.

Cinquina P., Rifiuti. Manuale tecnico-normativo, Pozzuoli 2010.

Kowalczuk P., Mieszkańcy Neapolu protestujq, góry śmieci rosnq, „Rzeczpospolita" z dnia 7 stycznia $2008 \mathrm{r}$.

Ramacci L. (red.), Il nuovo codice dei rifiuti. Commentato con la giurisprudenza, Piacenza 2011.

Rizzuto M., Sanna C., Guida all'applicazione del SISTRI. Adempimenti, procedure e sanzioni, Roma 2010.

Rosalba M., Compendio normativo per la gestione dei rifiuti e la bonifica dei siti inquinati - Commento organico della Parte IV, coordinata con la Parte I, del codice dellambiente Aggiornato al D.P.C.M. 27 aprile 2010. Modifiche al Modello unico di dichiarazione ambientale, Santarcangelo di Romagna 2010.

Kontakt e-mail:

karolinaszuma@gmail.com 